\title{
Studies of the Prefabricated Housing Construction Market in Poland
}

\author{
Elżbieta Radziszewska-Zielina, Monika Gleń \\ Tadeusz Kościuszko Cracow University of Technology \\ Faculty of Civil Engineering, Section of Technology and Building Management \\ e-mail: eradzisz@izwbit.pk.edu.pl
}

\begin{abstract}
The directions of development of the construction market are not only related to the need to own one's own home but also to increasing functional and economic requirements and conditions of sustainable development. The perception and understanding of prefabrication in housing construction are undoubtedly starting to change. Sustainable construction criteria may constitute a significant turning point and support for the development of new prefabricated housing construction technologies. Entrepreneurs are slowly perceiving an opportunity for the development of prefabrication in the construction market. The implementation and popularisation of ready-made homes will undoubtedly constitute a favourable change in the Polish construction market; however, this will require a modification of habits. This article presents an historical analysis of the development of the prefabricated housing construction market as well as an attempt to answer questions concerning the future of prefabrication in housing construction in Poland based on the conducted studies.
\end{abstract}

Key words: prefabrication, housing construction, sustainable development, market studies, survey.

\section{Introduction}

The directions in which the construction market is developing are related not only to the need to own one's own home but also to increasing functional and economic requirements. Within the framework of international cooperation at the International development design summit, better technological solutions that speed up the construction process and that are beneficial in both economic and ecological terms are being sought. The new lean approach to management in construction presented by scientists such as Spišáková and Kozlovská [1] is intended to make it easier for companies to achieve a very high level of efficiency, competitiveness, and flexibility in production systems. Considering the massive amount of construction waste, a solution to the problem is being sought in the application of modern MMC construction programmes [2], which concern, above all, the production of structures in factories, minimisation of defects in residences, and reduction of energy and waste. The potential and opportunity for achieving such results is perceived in modern prefabrication, among other 
methods. Interest in prefabrication technology, mainly in the determination of the current state of prefabrication in Slovakia, was the subject of an analysis conducted by [3]. Studies were conducted using the survey method on a group of contractors specialising in the construction of various types of buildings. Until now, conventional technology has enjoyed the greatest popularity on the Polish housing construction market, although prefabrication has also enjoyed its moments of triumph. For many years, Poles have maintained the conviction that the only good house is a conventionally built brick house. When it comes to methods of erecting residential buildings, the variety of choices is constantly being expanded by new solutions. More and more Poles are slowly starting to appreciate the advantages of light prefabricated construction, especially the short time needed for investment completion related to this method. Time pressure, as one of the leading points impacting contractors' decisionmaking processes, has a negative influence on the quality of constructed buildings and creates hazards resulting from the necessity to speed up the construction process. Studies and analyses conducted on 55 buildings confirm the significance of this problem [4]. An increasing number of companies specialising in the construction of residential buildings are starting to see their future in offering the construction of houses using prefabricated concrete, wood, or wood-derivative technology. The opening of Poland to the foreign market and its entry into the European Union, as well as the requirements of sustainable development, have had an undoubted influence on the development of housing prefabrication in Poland $[5,6]$ Even though prefabrication is currently applied and appreciated by engineers who build civil engineering structures, it has still not yet gained recognition among clients on the housing construction market in Poland. The authors hope that this will slowly start to change.

This article is an attempt to answer the question concerning the revival and direction of development of prefabrication technology in the housing construction market in Poland. The dependency between the quality of life of consumers and the change in users' needs in the process of purchasing fixed assets, as proven by [7] is valid and observable in the field of construction. The authors applied the same research methods that were used in Gabor's analysis of the housing construction market, that is, survey studies and statistical data. Despite differences in the choice of the fixed asset and social aspect, the obtained results are concurrent in global terms in both cases; furthermore, they confirm the validity of the research hypothesis assumed by the authors of the article. In addition the above survey studies, SWOT analysis was conducted to study the position of prefabrication on the housing construction market [8]. The concept of sustainable development, implemented in Poland after its entry into the EU, is an opportunity to popularise prefabrication in housing construction in the country. It is strictly related to life- cycle assessment of construction products and their impact on the environment. LCA of construction products applied in a building encourages a complete analysis of the life cycle of a building as a whole. Due to the requirements of sustainable development, numerous researchers undertake research in order to assess the life cycle of single-family residential buildings or their elementary parts; such methodologies include: Banaitiene, Turskis [9], Kvederyte, Zavadskas and Kaklauskas [10], Zavadskas, Ustinovičius, Gintautas and Kutut [11]. The research takes into account prefabrication due to its potential, perceived in the context of sustainable development in the construction industry. For that reason, ready-made houses arouse interest, the prefabrication technology is becoming noticeable and is regaining its popularity on the housing construction market. The researchers: Ciegis, Ramanauskiene and Martinkus [12] point to the thematic multidimensionality of the concept of "sustaineble development", which undoubtedly 
facilitates the technological development of prefabrication in many areas of the construction industry in Poland. Based on a developed mathematical algorithm, an index system was created [13] which has proved to be very useful and is frequently used to study the housing construction market. Viteikiene and Zavadskas [14] applied the index methodology in their assessment of residential areas in terms of their stability, which in the context of building a house "out of a box" is very significant. According to studies conducted by Štreimikienè and Barakauskaitė-Jakubauskienè [15], there are no generally accepted objective indices for measuring and comparing the quality of life in EU countries. A ready-made house, as a product, should have an appropriate and explicit place in the minds of potential buyers in order to maintain a presence on the housing construction market. High quality and a good brand are no longer sufficient. Widely developed conventional technology has a well-defined position on the Polish housing construction market, which makes it decidedly more difficult for prefabrication to assume a competitive position. Ostasevičiūtė and Šliburytė [16] present three product positioning models, XYZ, IDU, and STP, whose qualities can be applied in practically any field. For companies implementing prefabrication in the housing sector, acquaintance with the various approaches and notions of potential investors forms a basis for assuming the appropriate strategy of action. The validity of the direction and scope of studies assumed by the authors concerning the needs and preferences of clients has also been confirmed by studies presented by Egemen and Mahamed [17]. Analysis of the results showed a divergence of perspectives and expectations specified by both parties of the construction process; and this may be an element which hinders the dynamic development of the prefabrication technology on the housing construction market. Knowledge management is taking on greater significance, and, according to Radović Marković [18] companies that fully utilise the potential of their entire organisation in the fast-changing business environment will achieve success in the future. Falkenbach [19] conducted a survey concerning the selection criteria for the market of international real estate investments. The results indicate that the most important factors for the selection of the market by investors include the security of property rights and title as well as the expected return on the real estate investment. The process of market selection is also affected by the factors, undoubtedly resulting from economic changes over time, that show the maturity of the market of a given country. Although the study identified the position of investors, it did not address buyers' preferences (structured differently in each country), which significantly affect the success or failure of an investment. The strategy based on multivariate data analysis proposed by researchers Burinskiene and Rudzkiene [20] allows one to evaluate the prognoses and establishment of conditions favourable for investments and for developing the strategy for coherent economic and social development of regions. Unquestionably the price is among the criteria for the choice of apartments, which is also confirmed by market research conducted by the present authors. Raslanas, Tupenaite and Šteinbergas [21] conducted a study involving the comparison of flats in south-east London and Vilnius. Mathematical analysis showed that the average prices of apartments in Vilnius are 4 - 5 times lower compared to the prices of flats in south-east London. The financial value of the flats was determined by factors such as living space, transport, age and type of building.

In the case of prefabrication, the historical development of prefabrication technology in housing construction should also be accounted for. The relationships between the history of construction and its current trends were also perceived by Skibniewski and Zavadskas [22], albeit in a somewhat different context than is presented by the authors of this article. They 
directed their attention to the continuity of the creative thought of architects and engineers of the previous century, whose ideas and achievements are now being used to develop construction technology. Prefabrication in housing construction is sometimes still associated with prefabrication in the People's Republic of Poland, which currently elicits extreme emotions and conjectures as to the durability of large-panel buildings. The forecasted life of prefabricated apartment buildings is 100 years; however, accurate estimation of the limits of the technical wear of a building and/or its elements is no simple task. If an incorrect computational procedure is used to define the life of a building/element, serious errors can be made. This was proven analytically by Konarzewska and Konarzewski [23] based on formulas determining the life of a studied element over time. Furthermore, there is the problem of the energy efficiency of 'housing complexes' that are not adapted to EU requirements or development criteria implemented in the country. In their study of the relationships between the intensiveness of energy consumption, economical efficiency, and the primary motors of economic development, Bojnec and Papler [24] proved that intensive technological development of products (and exports) reduces a country's energy spending. This is related to the restructuring of energy-consuming branches of industry, including construction, into a more advanced form. In this case, the application of prefabrication technology has its raison d'être, and its technological advantages should be recognised more and more over time in Poland. The method for making an effective choice of building elements requiring renovation proposed by Krack and Zavadskas [25] is an appropriately adapted version of Moor's multi-criteria method and the MULTIMOORA method. Besides a building's durability and energy functionality, the optimisation of a building's construction costs is also important for both contractor and investor. Comparison of the costs of construction including specification of alternative prefabricated construction systems, as was done by Abdallah [26] in the case of a school building, is recommended for the optimisation in the housing construction market in a given country. However, attention must be paid to the difficulties related to planning and execution present during construction processes and to their negative impact on the efficiency of quality assurance systems in construction. According to Karlowski and Paslawski [27] an effective method of reducing disruptions is to apply a system for monitoring the environment which generates such disruptions.

There are many publications on the subject of prefabrication technology written from an engineering perspective; however, there are very few market research and papers indicating the future of the prefabricated housing construction market in Poland. This article presents an historical analysis of the development of the prefabricated housing construction market as well as an attempt to answer questions concerning the future of prefabrication in housing construction in Poland based on conducted studies. The research methods applied were: analysis of available documents and scientific descriptions, including some from the Central Statistical Office, using the desk research method and the survey method.

The paper analyses the historical development of the prefabricated housing market and attempts to answer questions concerning the future of prefabrication in the housing in Poland on the basis of research. Currently in Poland there is no information on this topic or if it exists, it is not widely available. There are more and more new, ready-made houses. Taking into account the fact that in many countries the construction of prefabricated houses is a standard while in others it is an only recently implemented technological market innovation, it is worth considering the facilitation of the flow of information on the investment results 
detailing the technological solutions used. An analysis of the development of the housing market taking into account the implemented technologies and the requirements of sustainable development in the construction industry may bring undoubted benefits in numerous areas of investment activity in many countries. Conducting research on the changes and preferences on the housing market in a given country, and particularly popularisation of the results obtained from the analysis, will greatly improve the functioning of the construction market and will thus contribute to the economic prosperity of the cooperating countries, focused on sustainable development. The beneficiaries will include the enterprises and investors willing to engage in investment activity by offering technological solutions outside their own country, without incurring the unnecessary risk of the decision-making process on both sides of the process. The present paper and the issues discussed here are therefore a step towards an active dialogue on the subject addressed primarily to contractors and specialists having in mind the conscious, sustainable development of the housing market as well as the economic growth of the cooperating countries: the European Union.

\section{Development of the housing market against the background of economic transformations in the country}

\subsection{The beginnings of prefabrication in Poland}

Housing construction in the period 1945-90 underwent tremendous changes related to the economic situation in the country. In the postwar years, Poland was focused on reconstruction, and the housing deficit was very great. The lack of technical resources limited technological capabilities, so that housing construction was based on conventional technology, which was partially industrialised due to the necessary minimisation of the time of investments.

The undiminishing demand for new housing resulted in the development of new technological and systemic solutions. The economic recession of the western countries that took place in the 70s was the beginning of the development of prefabricated construction in Poland. Austria, France and Germany started ridding themselves of prefabrication technology by exporting 'home factories' to socialist countries interested in the 'modern' systemic solution [28]. The USRR took advantage of the offer and started to construct ready-made housing estates on a massive scale, and Poland followed in its footsteps not long afterwards. Several large-panel construction systems were developed in Poland in the $60 \mathrm{~s}$, but such structures had not yet become dominant in Polish construction sites. In 1966, only $24.6 \%$ of apartments were built using large-panel prefabrication technology. Technology using the large-block system enjoyed greater popularity, and $31.5 \%$ of apartments were built using this method during the mid-50s [29]. The shares of technologies for raising apartment buildings in the period 196585 are presented in in Table 1.

Table 1: Shares of individual technologies for raising apartment buildings in Poland in the years 1965-85; source:[29]

\begin{tabular}{|l|c|c|c|c|c|}
\hline Technologies & 1965r.[\%] & 1970r.[\%] & 1975r.[\%] & 1980r.[\%] & 1985r.[\%] \\
\hline conventional & 45 & 18 & 6 & 1 & 2 \\
\hline large block & 30 & 56 & 35 & 19 & 16 \\
\hline
\end{tabular}




\begin{tabular}{|l|c|c|c|c|c|}
\hline monolithic & 10 & 4 & 3 & 1 & 9 \\
\hline skeleton & 0 & 0 & 1 & 0 & 3 \\
\hline large panel & 15 & 22 & 55 & 79 & 70 \\
\hline
\end{tabular}

The tumultuous social transformations and the disintegration of social structures that took place at the end of the $80 \mathrm{~s}$ had a negative impact on investments in the housing construction sector. This was a time of complete disorientation in terms of decision-making. No specific long-term directions of activity or strategic goals were set during this time. In many fields of construction, activities were undertaken that would lead to the modernisation of the existing production base. As a result of the rationalisation of processes in the national economy, most legal regulations, including housing norms (1991), lost their legal force. The State Centre for Strategic Studies was established in 1995 for the purpose of determining the directions of the country's spatial and social development. Despite all of the measures that were taken, the housing construction market collapsed. Many branches of the state economy were privatised, while unprofitable state enterprises were liquidated, including home factories [30].

\subsection{Analysis of the housing construction market in the years 2007-2013}

The information from the Central Statistical Office in Warsaw used in this work enabled the determination of the approximate changes of technological preferences in housing construction. However, it should be remembered that statistical data cannot precisely reflect the actual situation on the market. Information was collected from companies employing more than 5 persons. Therefore, construction microcompanies are omitted in the statistics, but in reality, they are of importance in home construction.

\subsubsection{Preferences in technologies for building new housing assets in the years 2007-2009}

During the period 2007-2009, the dominant method of erecting multi-family apartment buildings was the improved conventional method. About $75 \%$ of total building area was built using this method in 2008 , which reflected a $1 \%$ reduction relative to the previous year. In 2009 , the share of conventional technology in total volume amounted to $76.1 \%$ (Table 2).

The monolithic method held second place, with a share in 2007 of $20 \%$. This share grew by $3 \%$ in the following year and fell to $20.5 \%$ in 2009 . In 2008 , a reduction from $4 \%$ to $2 \%$ of the volume of buildings constructed using other technologies was observed, including prefabrication, and in 2009, there was additional growth, to $3.4 \%$. The following main technologies can be distinguished among them: large panel, large block, timber frame (Canadian).

Table 2: Residential buildings commissioned for use according to construction methods; source:[31,32]

\begin{tabular}{|l|c|c|c|}
\hline \multirow{2}{*}{$\begin{array}{l}\text { Construction } \\
\text { technology }\end{array}$} & \multicolumn{3}{|c|}{ Construction volume [\%] } \\
\cline { 2 - 4 } & $\mathbf{2 0 0 7}$ & $\mathbf{2 0 0 8}$ & $\mathbf{2 0 0 9}$ \\
\hline Conventional & 76.0 & 75.0 & 76.1 \\
\hline Monolithic & 20.0 & 23.0 & 20.5 \\
\hline Other & 4.0 & 2.0 & 3.4 \\
\hline
\end{tabular}


Considering the number of buildings constructed using various technologies, approximately $86 \%$ of residential buildings were built using conventional technology in 2009. Monolithic construction took second place (far behind the conventional method, with an $11 \%$ share). Prefabricated construction methods had only a small share, with only $3 \%$ of buildings constructed using this technology.

In private construction, conventional technology enjoyed a great deal of interest. The main factors that were decisive in the popularity of this technology were the capability to construct a building independently and to adapt the rate of construction according to the investors' financial capabilities.

The average time of construction of multi-family buildings in 2008 was 24.3 months, that is, 2 months shorter relative to the previous year. In 2009, the cycle was shorter by 0.7 months. In comparison, the duration of private home construction amounted to over 5 years (about 63 months) and was shorter by 4 months relative to the previous year, i.e. 2008 [32].

\subsubsection{Preferences of buyers on the housing market in the years 2010-13}

According to data from the Central Statistical Office [33, 34, 35] the dominant method of construction of residential buildings in successive years over the time period 2009-13 was still the improved conventional method. Its share in the volume of new housing buildings in quarters I-III of 2009 amounted to $72.4 \%$. In subsequent years, this tendency grew successively. In 2011, it increased in comparison to the previous year, i.e. 2010, and equalled 91.5\%. The share of residential building volume constructed using monolithic technology decreased to $8.0 \%$ in comparison to the year 2010. A similar situation took place in largepanel construction (decrease to $0.1 \%$ ) and large-block construction (to $0.5 \%$ ). The share of other methods did not exceed $0.05 \%$. Interest emerged in wood construction technology, mainly the timber frame (Canadian) method; however, it is worth noting that no investments were realised using this technology in the previous year.

Table 3: Methods of erecting residential buildings in the years 2010-13; source: [33, 34, 35]

\begin{tabular}{|l|c|c|c|c|}
\hline \multirow{2}{*}{$\begin{array}{l}\text { Construction } \\
\text { technology }\end{array}$} & \multicolumn{4}{|c|}{ Buildings [number, \%] } \\
\cline { 2 - 5 } total & $\mathbf{2 0 1 0 r}$. & $\mathbf{2 0 1 1 r}$ & $\mathbf{2 0 1 2 r}$. & $\mathbf{2 0 1 3 r}$ \\
\hline \multirow{2}{*}{ conventional } & $\mathbf{1 3 6 0}$ & $\mathbf{2 9 9 8}$ & $\mathbf{5 9 3 8}$ & $\mathbf{2 1 0 6}$ \\
\hline \multirow{2}{*}{ monolithic } & 1218 & 2945 & 5814 & 2061 \\
\cline { 2 - 5 } & $90 \%$ & $98 \%$ & $98 \%$ & $98 \%$ \\
\hline \multirow{2}{*}{ large block } & 106 & 44 & 106 & 44 \\
\hline \multirow{2}{*}{ large panel } & $7,8 \%$ & $1,5 \%$ & $1,8 \%$ & $2,1 \%$ \\
\hline \multirow{2}{*}{$\begin{array}{l}\text { wooden } \\
\text { construction }\end{array}$} & $0,0125 \%$ & $0,001 \%$ & $0,0003 \%$ & $0 \%$ \\
\hline \multirow{2}{*}{ other } & 11 & 0 & 1 & 0 \\
\cline { 2 - 5 } & $0,8 \%$ & $0,0 \%$ & $0,0 \%$ & $0,0 \%$ \\
\cline { 2 - 5 } & 0 & 1 & 0 & 1 \\
\cline { 2 - 5 } & $0,0 \%$ & $0,0 \%$ & $0,0 \%$ & $0,0 \%$ \\
\cline { 2 - 5 } & $0,6 \%$ & $0,2 \%$ & $0,3 \%$ & $0,0 \%$ \\
\hline
\end{tabular}


Considering the number of buildings built over the years 2009-13 using individual technologies, a sudden drop of interest in prefabricated construction is visible. A rising, although slight, tendency in the share of large-panel and large-block technologies was observed in 2010 [33, 34, 35].

A comparison of the number of residential buildings constructed using prefabrication technology and using conventional technology shows that this is a negligible share of the market and the resulting market success is insignificant. In 2009, the share of prefabrication technology relative to all applied methods was only $11.5 \%$. In the following year, a decrease to $9.9 \%$ occurred, and in 2011 , the demand for construction with prefabricated elements was reduced by $1.6 \%$, down to only $0.05 \%$ of the share of wood structures in $2013[33,34,35]$.

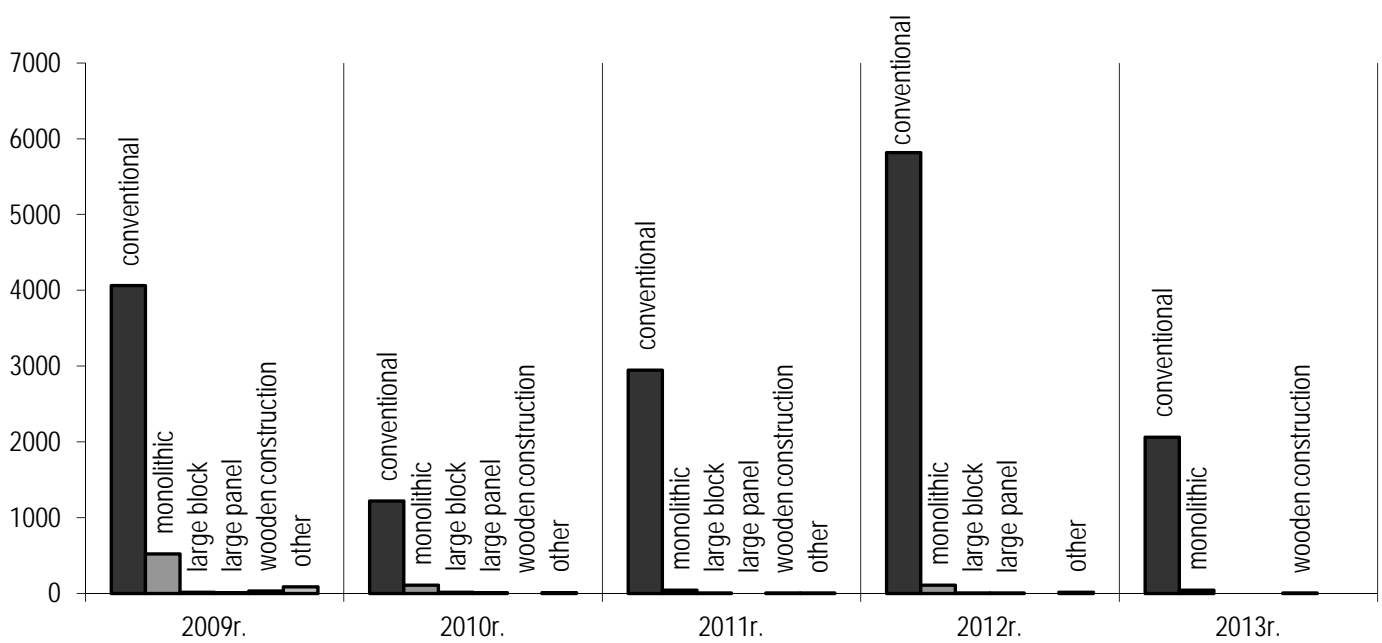

Figure 1: Share of residential building construction methods in the years 2009-13; source:

$[33,34,35]$

Despite little interest in prefabrication technology in residential construction, one cannot forget private construction, which was not accounted for in this analysis. The volume of information and reports appearing on the subject of new home construction systems using prefabrication technology indicates rising interest in this technology in this field. Several years ago, very few who wished to build a house over a very short period of time made an effort to obtain information on the subject of home construction systems using prefabrication technology. It was possible to obtain such information only on the websites of foreign companies, e.g. from Germany, Sweden, Scandinavia, or Finland, where this technology is used to the same extent as conventional technology is used in Poland. Today one can easily learn about the possibilities of building 'ready-made and packaged homes'. More and more companies in Poland are basing their house-building operations exclusively on the prefabrication system because they see an opportunity for development in doing so.

\section{Authors' survey studies}

Survey studies were conducted among potential clients of the housing construction market. The survey was developed in electronic form and uploaded to an online base on the website 
www.ankieta.pl. The form was made available to interested parties in 2012. Eighty individuals took part in the study. These studies are to be considered as having the nature of a survey. Information concerning three thematic areas was collected:

- general information about the surveyed individuals (age group, gender, civil status),

- preferences concerning the residential building (apartment or home, type of investment market: primary/secondary, choice of technology, factors impacting the choice of technology),

- opinions on the subject of prefabrication in residential construction (associations with prefabrication, market opportunities, competitiveness of technology on the housing construction market).

\subsection{General information about surveyed individuals}

Survey studies were conducted on a group of individuals above 19 years of age. For the most part, individuals aged 20 to 30 took part in the study (66\%). Of those surveyed, $54 \%$ were women and $46 \%$ were men (Fig. 2). The fact that the largest number of respondents are young people with the greatest influence on the future of the country and on the directions of development of the construction market increases the chances of drawing valid long-term conclusions from analysis of the survey and of estimating the actual opportunities for development of prefabrication technology on the residential construction market.

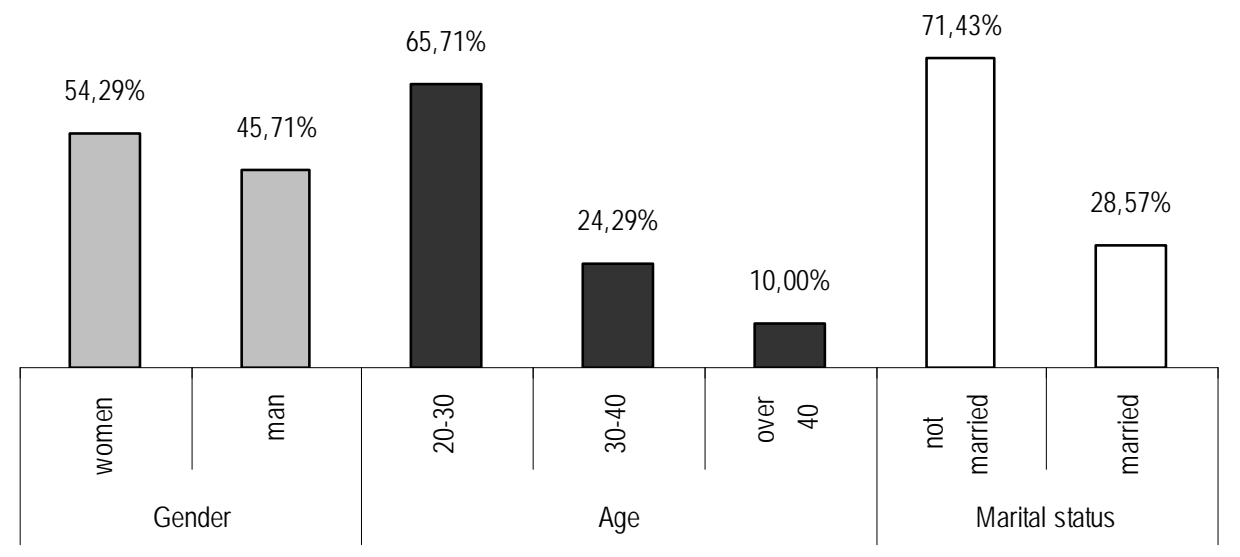

Figure 2: Information about individuals surveyed in the study; source: Authors' chart

\subsection{Preferences concerning a residential building}

The results unequivocally indicate that the financial expenditures made during the transaction and, subsequently, during the period of building use, were the deciding factor for purchasing a specific building, with $68.57 \%$ of respondents indicating the purchase price as a prime criterion for their choice.

The average respondent would rather reside in his/her own home than in an apartment in an apartment building; $87 \%$ of those studied made this choice. For $83 \%$ of respondents, whether a purchase is made on the primary or secondary market is of no great significance. Only $17 \%$ unequivocally indicated a preference in this regard, of whom 13\% indicated the primary market. Is the selection of the market on which the purchase will be made and of the type of 
building significant in regard to the development of prefabrication? Yes, very significant. A high level of interest in the secondary market reduces demand for newly-built residential buildings. Stagnation in residential construction limits interest in new methods of building construction and will thus hinder the popularisation of modern prefabrication. The fact that clients would rather own their own home than an apartment is also confirmed by studies of the Central Statistical Office [35]. The method of constructing buildings using prefabrication technology in the field of multi-family residential construction is not popular. In consequence, companies offering the construction of residential buildings using systems based on prefabricated technology should focus more on individual private clients interested in building a home.

\subsection{Popularisation of prefabricated construction against the background of conventional technology}

The following factors have an undoubted influence on the choice of home construction technology:

- costs of construction (from the construction of the foundations to completion, inclusively),

- the building construction system (independent or including hiring of the appropriate companies),

- financial liquidity (which regulates the time and rate of performed work),

- the site of construction (location, shape, and area of the lot, geotechnical soil parameters, accessibility to traffic),

- individual client preferences,

- the deadline for construction of the buildings and the time clients have available.

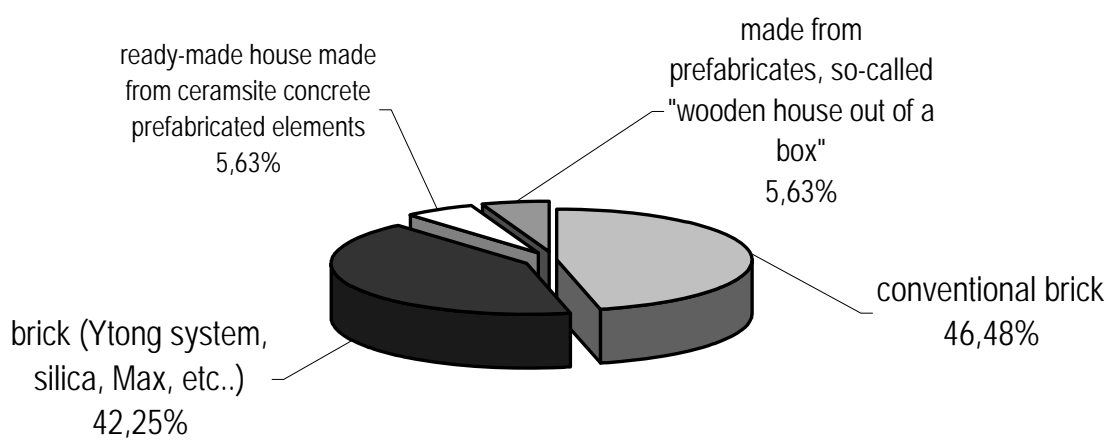

Figure 3: Choice of home construction technology; source: Authors' chart

According to the conducted studies, as many as $88.73 \%$ of those surveyed would rather build their own home using conventional technology, with only $11.26 \%$ using prefabrication technology (Fig. 3). Of those surveyed, 52.7\% indicated the capability of independent building construction as a factor influencing their choice of home construction technology, while $24.3 \%$ indicated an attachment to conventional construction. Both factors $(77 \%$ total) indicate the dominance of systems using conventional technology over modern prefabrication. $22.9 \%$ of those surveyed indicated the speed of construction of a house using ready-made elements, which can be considered to be the main advantage of 'ready-made home' construction. Not one 
among those surveyed indicated a lack of trust in technological novelties as an argument that could effectively inhibit the development of prefabrication in the scope of residential construction (Fig. 4).

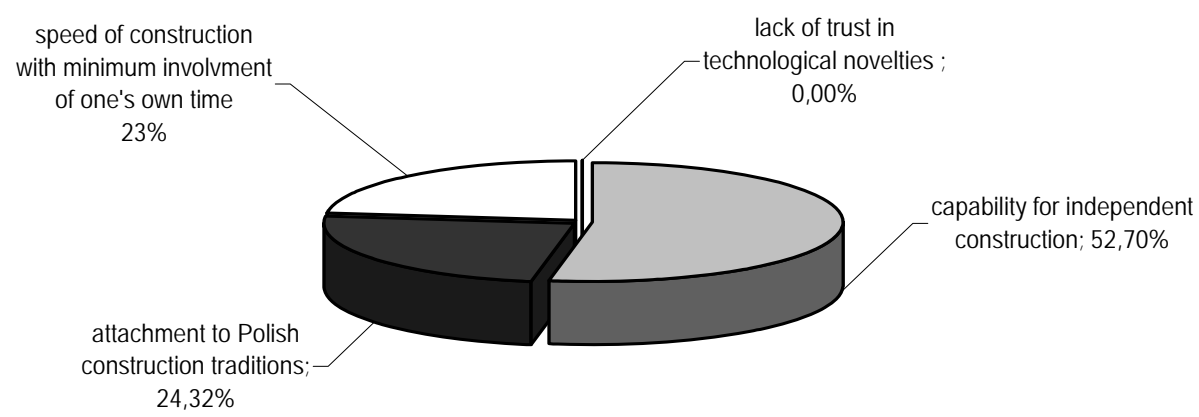

Figure 4: Factors that influence the choice of house construction technology; source: Authors' chart

When an apartment is being purchased, the technology used to build is not as significant as in the case of a house. For $62.86 \%$ of those surveyed, technology is not important, while comfort of use and the price of purchase are. Of the rest of those surveyed, $24.29 \%$ would prefer an apartment built using small-scale and $12.86 \%$ would choose large-scale construction technology (Fig. 5).

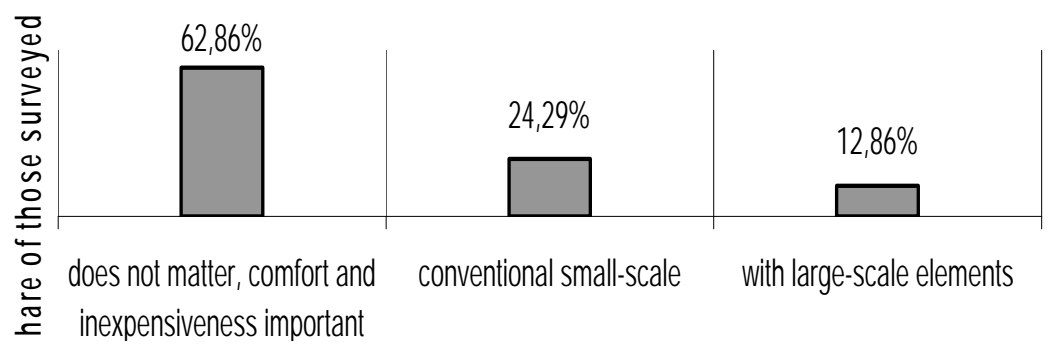

Figure 5: Choice of apartment construction technology; Source: Authors' chart

The fact that buildings built in the 1960s using prefabrication technology are still used and are in demand on the secondary market of residential real estate is an additional confirmation of the above results. Undoubtedly, the main advantage of these apartments is their significantly lower price in comparison to newly-built buildings. So why is there so little interest in house construction using prefabrication technology? Do associations with prefabrication from the People's Republic of Poland era discourage people from building houses from ready-made elements? To dispel doubts and determine the influence of the past, that is, of 'large-panel' construction on the current perception of prefabricated systems, potential clients were asked what their associations with prefabrication in residential construction were. The results of these studies are presented in Fig. 6. 


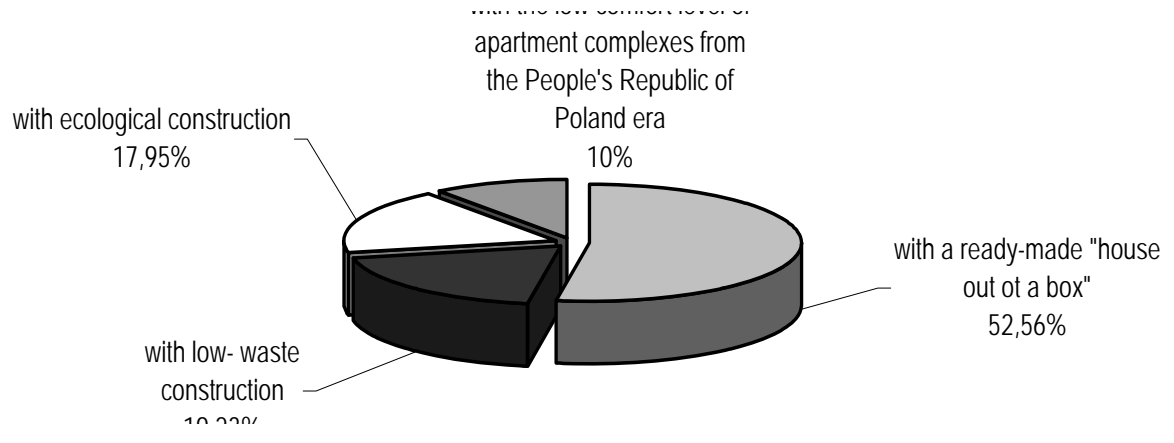

Figure 6: What are Poles' associations with prefabrication in residential construction?; Source: Authors' chart

Certainly, associations with systems using modern prefabrication technology do not have their source in the past but are based on current information in the media. Over $89 \%$ of those surveyed link prefabrication with ecology, material savings, and the concept of a 'home out of a box'. Only $11 \%$ of those studied perceived any relationship with the negative aspects of living in an 'apartment complex from the People's Republic of Poland'. The low level of interest in the construction of ready-made houses is undoubtedly related to the strong market position and development of systems using conventional technology.

\section{Conclusion}

Although today the perception of prefabricated technology is much worse than that of conventional technology, it does have its advantages. The prospect of sustainable development that is being achieved from year to year in countries of the European Union may contribute to a growth of interest in prefabricated construction systems, but the main road to success for prefabrication is a reliable construction company that can boast knowledge of technology and capable performance of services. The pace of life and the search for comfortable and convenient decision-making solutions conclusively speak in favour of prefabrication technology systems. The time required to build a ready-made house from prefabricates is only several days.

Construction companies that favour prefabrication in residential construction are presenting themselves in a new and very advantageous light. Ready-made houses 'out of a box' are becoming more and more noticeable and even competitive on the housing construction market relative to conventional technology. This is not only because of economic changes in the country, which were mainly initiated by Poland's entry into the European Union, but also because of construction capabilities that cannot be achieved with the use of small-scale elements. The perception and understanding of precfabricated housing is undoubtedly starting to change, which for foreign investors and entrepreneurs constitutes an opportunity to undertake investment activity. The implementation and popularisation of ready-made homes will undoubtedly constitute a favourable change in the Polish construction market; however, this will require a modification of habits. The authors hope that the effects that modern prefabrication will bring about in housing construction will be visible, along with the rate of its development, in several years. 


\section{References}

[1] Spišáková M., Kozlovská M.(2013). Lean production as an innovative approach to construction. Journal of Civil Engineering, 8(1), (2013), pp. 87-96.

[2] Kozlovská M., Spišáková M.(2011). Modern methods of construction vs. construction waste, International Multidisciplinary Scientific GeoConference, pp. 483-490.

[3] Župová L., Kozlovská M.(2013). Precondition for wider use of prefabricated construction methods, Teorija i praktika budivnictva (756), pp. 105-109.

[4] Kozlovská M., Struková Z., Tažiková A. (2010). Access to construction time objectiveness, Organisation, Technology and Management in Construction : An International Journal, 2(2), pp. 200-206.

[5] Czarnecki L., Tworek J., Wall S. (2012). Inżynier budownictwa -artykuł „Budownictwo zrównoważone w Polsce". 24-28.

[6] Rozporządzenia Parlamentu Europejskiego i Rady UE nr 305/2011 z dn.9.03.2011r.załącznik 1, 34 (Directives of the European Parliament and Council of the European Union No. 305/2011 of 9 March 2011, attachment 1, 34)

[7] Gabor M. R. (2013). Endowment with Durable Goods as Welfare Indicator. Empirical Study Regarding Post-Communist Behavior of Romanian Consumers. Engineering Economics, 24(3), pp. 244-253.

[8] Radziszewska-Zielina E., Gleń M. (2013), Szanse i zagrożenia dla budownictwa mieszkaniowego z prefabrykatów. Inżynieria Morska i Geotechnika, No. 5, pp. 392-396.

[9] Banaitiene N., Turskis Z. (2004). Decision support for the evaluation of building life cycle effectiveness. Technological and Economic Development of Economy, 10(2), pp. 57-66.

[10] Kvederytè N., Zavadskas E. K, Kaklauskas A. (2000). Multiple Criteria Multivariant Design of a Building Life Cycle. Journal of Civil Engineering and Management, 6(2), pp. 128-142.

[11] Zavadskas E. K., Ustinovičius L., Turskis Z., Gintautas A., Kutut V. (2005). Estimation of external walls decisions of multistorey residential buildings applying methods of multicriteria analysis. Technological and Economic Development of Economy, 11 (1), pp. 59-68.

[12] Ciegis R., Ramanauskiene J., Martinkus B. (2009). The Concept of Sustainable Development and its Use for Sustainability Scenarios. Engineering Economics, 62(2), pp. 28-37.

[13] Šaparauskas J.,Turskis Z. (2006). Evaluation of construction sustainability by multiple criteria methods Technological and Economic Development of Economy, 12(4), pp. 321-326.

[14] Viteikiene M., Zavadskas E. K.(2007). Evaluating the sustainability of vilnius city residential areas. Journal of Civil Engineering and Management, 13(2), pp. 149-155.

[15] Štreimikienė D., Barakauskaitè-Jakubauskienė N. (2012). Sustainable development and quality of life in Lithuania compared to other countries. Technological and Economic Development of Economy,18(4), pp. 588-607.

[16] Ostasevičiūtè R., Šliburytė L. (2008). Theoretical Aspects of Product Positioning in the Market. Engineering Economics, 56(1), pp. 97-103.

[17] Egemen M., Mahamed A. N.(2005). Different approaches of clients and consultants to contractors' qualification and selection. Journal of Civil Engineering and Management, 11(4), pp.267-276.

[18] Radović Marković M. (2008). Managing the organizational change and culture in the age of 
globalization. Journal of Business Economics and Management, 9(1), pp. 3-11.

[19] Falkenbach H. (2009), Market selection for international real estate investments. International Journal of Strategic Property Management, 13(4), pp. 299-308.

[20] Burinskiene M., Rudzkiene V. (2004), Comparison of spatial-temporal regional development and sustainable development strategy in Lithuania. International Journal of Strategic Property Management, 8(3), 2004, pp. 163-176.

[21] Raslanas S., Tupenaite L., Steinbergas T. (2006), Research on the prices of flats in the South East London and Vilnius. International Journal of Strategic Property Management, 10(1), pp. 51-63.

[22] Skibniewski M.J.,Zavadskas E. K.(2013).Technology development in construction: a continuum from distant past into the future. Journal of Civil Engineering and Management ,19(1), pp. 136147.

[23] Konarzewska M., Konarzewski A.(2006). Chosen aspects of defining technical wear of buildings, Technological and Economic Development of Economy, 12(3), pp. 200-203.

[24] Bojnec Š. \& Papler D. (2011). Economic Efficiency, Energy Consumption and Sustainable Development. Journal of Business Economics and Management, 12(2), pp. 353-374.

[25] Kracka M., Zavadskas E. K. (2013). Panel building refurbishment elements effective selection by applying multiple-criteria methods. International Journal of Strategic Property Management, 17(2), pp. 210-219.

[26] Abdallah A. (2007). Managerial and economic optimisations for prefabricated building systems. Technological and Economic Development of Economy, 13(1), pp. 83-91.

[27] Karłowski A., Pasławski G. (2008). Monitoring of construction processes in the variable environment. Technological and Economic Development of Economy, 14(4), pp. 503-517.

[28] Wojtkun G.(2011),Wielka płyta na styku żelaznej kurtyny, Przestrzeń i forma (15), pp. 476478.

[29] Dzierżewicz Z., Starosolski W. (2010),Systemy budownictwa wielkopłytowego w Polsce w latach 1970-1985, Wolters Kluwer Polska, pp. 15-16.

[30] Wojtkun G. (2008).Wielorodzinne budownictwo mieszkaniowe w Polsce. W cieniu wielkiej płyty, Przestrzeń i forma, (10), pp. 190-192.

[31] GUS „Budownictwo mieszkaniowe I-III kwartał 2008r., W-wa 2008,14. (Central Statistical Office 'Housing construction quarters I-III 2008', Warsaw 2008,14.)

[32] GUS „Budownictwo mieszkaniowe I-III kwartał 2009r.”,W-wa 2009,14. (Central Statistical Office 'Housing construction quarters I-III 2009', Warsaw 2009,14.)

[33] GUS „Budownictwo mieszkaniowe I-III kw. 2009-2011, W-wa,14. (Central Statistical Office 'Housing construction quarters I-III 2009-2011', Warsaw, 14.)

[34] GUS „Budownictwo mieszkaniowe,I-IVkw.2012r., W-wa 2013, 15. (Central Statistical Office 'Housing construction quarters I-IV 2012', Warsaw 2013,15.)

[35] GUS „Budownictwo mieszkaniowe I-II kw. 2013,W-wa 2013, 15. (Central Statistical Office 'Housing construction quarters I-II 2013', Warsaw 2013,15.) 